\title{
Article \\ Evaluation of Impurity Concentration Process and Mitigation Operation in Fuel Cell System for Using Biogas
}

\author{
Yutaro Akimoto $^{1, *(1)}$, Yuta Minei ${ }^{2}$ and Keiichi Okajima ${ }^{1}$ \\ 1 Faculty of Engineering, Information and Systems, University of Tsukuba, Tsukuba 305-8577, Japan; \\ okajima@risk.tsukuba.ac.jp \\ 2 Department of Risk Engineering, University of Tsukuba, Tsukuba 305-8577, Japan; s1920598@s.tsukuba.ac.jp \\ * Correspondence: akimoto@risk.tsukuba.ac.jp; Tel.: +81-29-853-5537
}

check for

updates

Citation: Akimoto, Y.; Minei, Y.; Okajima, K. Evaluation of Impurity Concentration Process and Mitigation Operation in Fuel Cell System for Using Biogas. Reactions 2021, 2 , 115-128. https://doi.org/10.3390/ reactions 2020010

Academic Editors: Sibudjing Kawi, Luis M. Gandía, Valérie Meille and Francesco Frusteri

Received: 30 April 2021

Accepted: 21 May 2021

Published: 25 May 2021

Publisher's Note: MDPI stays neutral with regard to jurisdictional claims in published maps and institutional affiliations.

Copyright: (C) 2021 by the authors. Licensee MDPI, Basel, Switzerland. This article is an open access article distributed under the terms and conditions of the Creative Commons Attribution (CC BY) license (https:/ / creativecommons.org/licenses/by/ $4.0 /)$.

\begin{abstract}
For a low-carbon society, it is necessary to extract hydrogen for fuel cells from biogas rather than from fossil fuels. However, impurities contained in the biogas affect the fuel cell; hence, there is a need for system and operation methods to remove these impurities. In this study, to develop a fuel cell system for the effective utilization of biogas-derived hydrogen, the compositional change and concentration of impurities in the hydrogen recirculation system under actual operation were evaluated using process simulation. Then, the mitigation operation for performance degradation using simple purification methods was evaluated on the proton exchange membrane fuel cells (PEMFC) stack. In the process simulation of the hydrogen recirculation system, including the PEMFC stack, the concentration of impurities remained at a level that did not pose a problem to the performance. In the constant voltage test for a simulated gas supply of biogas-derived hydrogen, the conditions for applying the methanation reforming and air bleeding methods were analyzed. As a result, methanation reforming is more suitable for supplying biogas-containing CO to the PEMFC stack for continuous operation.
\end{abstract}

Keywords: PEMFC stack; process simulation; methanation; air-breeding

\section{Introduction}

Proton exchange membrane fuel cells (PEMFCs) generate electricity using hydrogen and oxygen in the air. The hydrogen production method involves the extraction of hydrogen from fossil fuels such as natural gas and oil by steam reforming because the cost of production is lower than that of other methods. However, there is a need to reduce the use of fossil fuels in the future, and it is necessary to diversify hydrogen production to realize a low-carbon hydrogen society. Hydrogen production from waste-based resources can be divided into aerobic fermentation and anaerobic fermentation (methane fermentation); however, methane fermentation by anaerobic digestion has become mainstream. This is because methane fermentation produces a renewable energy source called biogas from livestock manure, and the digestate can be used as a high-quality fertilizer [1]. Methane fermentation is a biological process that occurs when organic materials decompose in the presence of metabolically active microorganisms and the absence of air. The biogas produced by this process consists primarily of methane ( $45-75 \%$ by vol.) and carbon dioxide (25-55\% by vol.), which can be converted into hydrogen-rich gas through combined steam and dry reforming. The production of hydrogen from biogas and its use in fuel cells has attracted attention as a clean hydrogen production method [2]. Biogases may also contain small amounts of nitrogen and sulfur oxide, which are more detrimental to PEMFCs than to power generators and solid oxide fuel cells [3]. Nishizaki et al. conducted a study on the use of biogas produced by methane fermentation in fuel cells [1]. The reformer of the PEMFC power generation system used in this study is steam reforming, which has a high reforming efficiency with small output. The reformer consists of a steam reforming reaction section, an aqueous gas shift reaction section, and a selective oxidation reaction section. 
The composition of the reformed gas was less than $10 \mathrm{ppm} \mathrm{CO}, 60 \% \mathrm{H}_{2}, 30 \% \mathrm{CO}_{2}, 6 \% \mathrm{~N}_{2}$, and $3 \% \mathrm{CH}_{4}$, which can be considered a crude purified gas with low purity. The composition of biogas is affected by the raw material input to the plant and the fermentation conditions. Changes in the amount of methane and the effect of water vapor concentration in the biogas during the fuel reforming process will also need to be studied in the future.

Hydrogen gas reformed from biogas contains a small amount of $\mathrm{CO}$, which has a significant impact on the power generation performance of fuel cells [4,5]. Platinum is used as the main catalyst in PEMFCs. Platinum is an excellent catalyst for the oxidation of $\mathrm{H}_{2}$ and is chemically stable in the PEMFC-operating environment; however, it causes severe $\mathrm{CO}$ poisoning at low temperatures [6]. $\mathrm{CO}$ adsorbs preferentially to $\mathrm{H}_{2}$ on Pt catalyst sites, as shown in Equation (1).

$$
\mathrm{CO}+\mathrm{Pt} \leftrightarrow \mathrm{Pt}-\mathrm{CO}
$$

This inhibits the adsorption of hydrogen and the electron dissociation reaction in Equations (2) and (3).

$$
\begin{gathered}
2 \mathrm{Pt}+\mathrm{H}_{2} \leftrightarrow 2 \mathrm{Pt}-\mathrm{H} \\
\mathrm{Pt}-\mathrm{H} \leftrightarrow \mathrm{Pt}+\mathrm{H}^{+}+\mathrm{e}^{-}
\end{gathered}
$$

The adsorption of $\mathrm{CO}$ is linear-bonded using one adsorption site and is considered to be Langmuir-type adsorption. The effect of CO on the I-V characteristics of PEMFCs was reported in a previous study [6]. The presence of $\mathrm{CO}$ in hydrogen fuel at the ppm level significantly reduced the PEMFC performance. As the $\mathrm{CO}$ concentration increased, the power generation performance at high current decreased because of the $\mathrm{CO}$ coating on the catalyst surface, which reduced the effective power generation area. The $\mathrm{CO}$ adsorption became pronounced in the low cell voltage region, which may affect the activation overvoltage.

As an inert gas, $\mathrm{N}_{2}$ is not electrochemically active in fuel cell applications and only shows a dilution effect on the fuel [7]. As the $\mathrm{N}_{2}$ concentration in the anode gas increases, the cell performance decreases because of the decrease in hydrogen partial pressure, which can be explained by the Nernst equation. When air is supplied to the cathode, it has been reported that the PEMFC cell can be operated without a significant performance loss if the $\mathrm{N}_{2}$ content in the anode gas is approximately $50 \%$ [8]. However, when a high concentration of $\mathrm{N}_{2}(80-90 \%)$ is present in the anode gas, a cell performance loss exceeding the above Nernst equation has been reported, which is considered to be owing to additional mass transport losses. It has also been reported that the effect of $\mathrm{CO}$ poisoning is more significant when hydrogen gas containing an inert gas and CO is supplied to the fuel cell [4]. In actual PEMFC stack operation, the anode fuel is often recirculated, which may cause $\mathrm{N}_{2}$ and other inert gases to stagnate and concentrate, further affecting the performance. The periodic purging of the anode gas and the adjustment of the recirculated gas are considered countermeasures against the decrease in hydrogen's partial pressure caused by inert gas retention.

$\mathrm{CO}_{2}$ is a significant component of biogas-derived hydrogen, usually constituting more than $20 \%$, and can cause a reverse shift reaction to form CO on the catalyst surface, most likely because of the electrochemical reduction reaction. Moreover, it has been reported that dilution by $\mathrm{CO}_{2}$ has a greater effect than dilution by inert gas [9]. However, experiments have shown that $\mathrm{CO}_{2}$ has little effect on PEMFC performance compared with $\mathrm{CO}[6,10]$, and some conclude that the performance degradation caused by $\mathrm{CO}_{2}$ is owing to the dilution effect [11].

In an operational system using biogas-derived hydrogen, impurities are concentrated in the circulating system if impurities are present in the fuel. Matsuda et al. analyzed the gas concentration in the circulating system of a fuel cell generating electricity with high-purity hydrogen or hydrogen with impurities [12]. Because this test was conducted in a single cell, the original fuel flow rate was low, and the amount of CO input into the circulation system was small, which may have affected the results. It is necessary to evaluate the transition of $\mathrm{CO}$ concentration under the fuel flow rate for the stack and consider the enrichment of inert gas for the use of biogas-derived hydrogen. 
In our previous study [13], we evaluated the effect of impurity components on the fuel cell stack performance to develop a fuel cell system for the effective utilization of impuritycontaining hydrogen gas, such as exhaust hydrogen, from a heat treatment furnace. In this study, for the effective utilization of biogas-derived hydrogen, the compositional change and the concentration of impurities in the hydrogen recirculation system under actual operation were evaluated using process simulation. Then, the mitigation operation for performance degradation using simple purification methods was evaluated on the PEMFC stack.

\section{Experiment and Its Conditions}

\subsection{Fuel Cell Stack System}

In this study, experiments were conducted using a 48-cell $1 \mathrm{~kW}$ PEMFC stack (Horizon: H-1000) [14], as shown in Figure 1. This PEMFC stack consisted of 48 cells, current collector plates, end plates, and rods. We used an open-cathode stack. Therefore, the installed fan supplied air to the cathode and cooled the stack, keeping the stack temperature below $65^{\circ} \mathrm{C}$. When the stack voltage dropped below $24 \mathrm{~V}$, the control unit shut off the load. The effective power generation area of the cell was estimated to be $88 \mathrm{~cm}^{2}$.

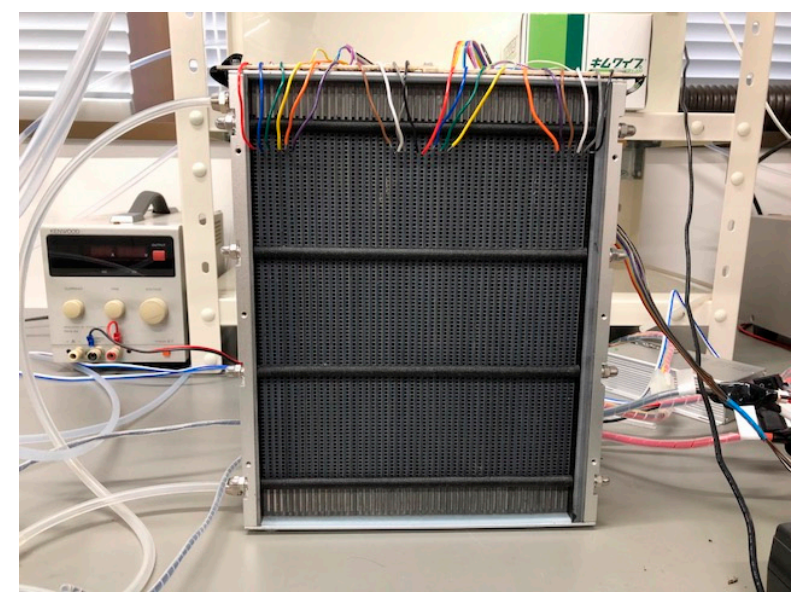

Figure 1. PEMFC stack.

Figure 2 shows a schematic diagram of the experiment using a PEMFC stack to supply hydrogen-containing impurities. The PEMFC stack was connected to an electronic load device (TAKASAGO: FK-1000L2), and a load-following operation was performed. A digital logger (HIOKI 8422-50) was used to record the operating current. A memory high coder (HIOKI: MR8870) was used to record the voltage waveform during the current interrupt test for the measured cell resistance $[15,16]$. In the biogas-derived hydrogen supply test, the gas from the $\mathrm{N}_{2}$ and $\mathrm{CH}_{4}$ cylinders was mixed with the hydrogen- and $\mathrm{CO}$-containing cylinders and adjusted to the specified concentration. The purge valve attached to the PEMFC stack was removed, and the fuel exhaust side was opened for the flow-type test.

The I-V and I-P measurements of the PEMFC stack measured in this experiment were performed when pure hydrogen was supplied. The measurement was used in a dead-end mode, in which the anode gas outlet is shut off, but a control valve purges the anode once every $10 \mathrm{~s}$ for $0.1 \mathrm{~s}$ to remove the water accumulated in the anode. The gas supply pressure was kept constant at $0.060 \mathrm{MPa}$. The load current varied from 0 to $41 \mathrm{~A}$, and the stack voltage and output power were measured after $2 \mathrm{~min}$ at each load current. The I-V and I-P curves of the stack are shown in Figure 3. $30.5 \mathrm{~V}$ was obtained at $35 \mathrm{~A}$, which is equivalent to the catalog specification value [14]. The maximum output power was $1190 \mathrm{~W}$ at $41 \mathrm{~A}$. 


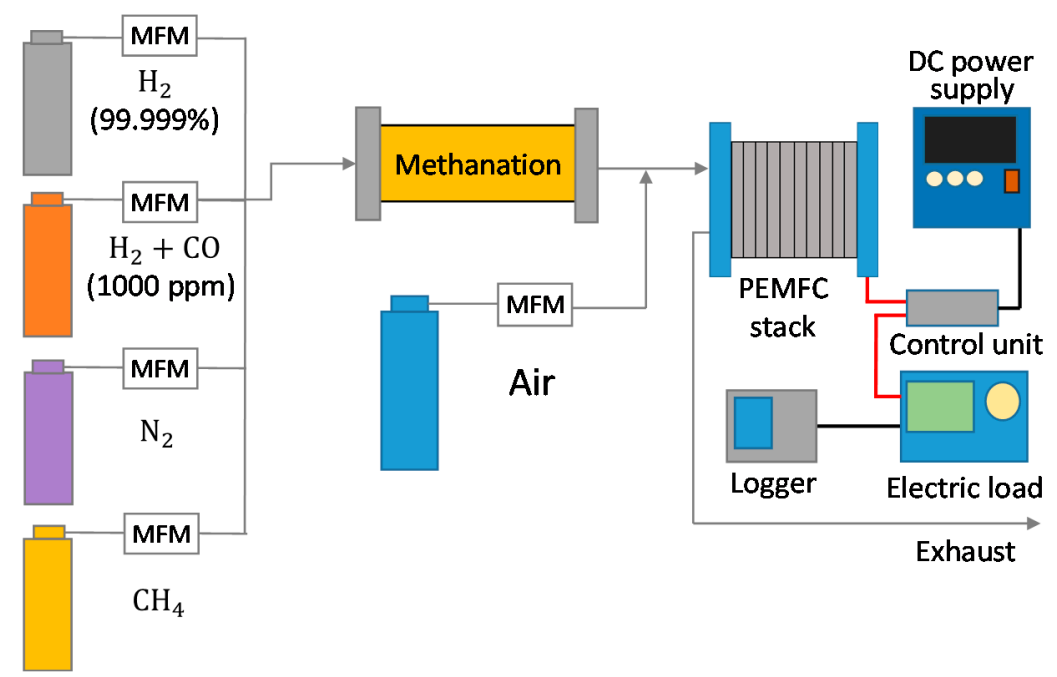

Figure 2. Schematic diagram of the experiment using a PEMFC stack to supply hydrogen-containing impurities.

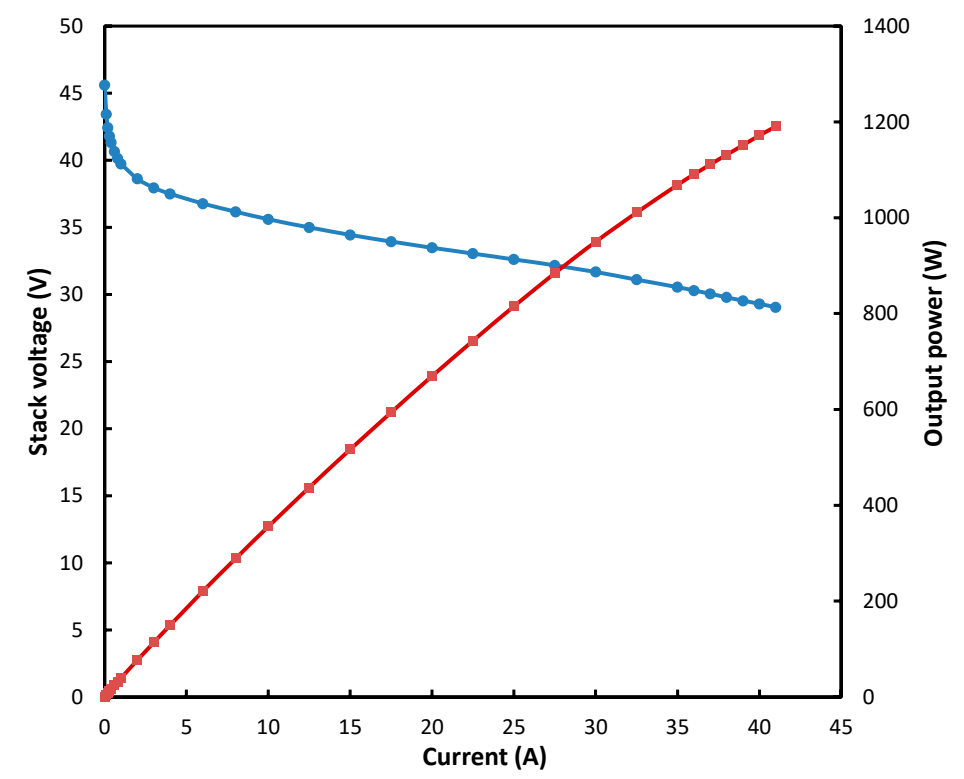

Figure 3. Performance of PEMFC stack.

\subsection{Simplified Purification System}

\subsubsection{Methanation Reactor}

One of the experiments was conducted using a methanation reactor as an external reforming method for impurities. The reactor was $2.76 \times 10^{-4} \mathrm{~m}^{3}$ and filled with nickel catalyst N111 or a nickel/alumina catalyst MT881 (JGC Catalysts and Chemicals Ltd., Kawasaki, Japan). The methane production reaction in the reactor is shown in Equations (4) and (5). The operating temperature of the reactor was maintained at $200{ }^{\circ} \mathrm{C}$ using a heater. The reactor was maintained at a temperature of $200{ }^{\circ} \mathrm{C}$ using a heater, and a $2 \mathrm{~h}$ pre-run with nitrogen and hydrogen was performed to reduce the catalyst in the reactor.

$$
\begin{aligned}
\mathrm{CO}+3 \mathrm{H}_{2} & \rightarrow \mathrm{CH}_{4}+\mathrm{H}_{2} \mathrm{O} \\
2 \mathrm{CO}+2 \mathrm{H}_{2} & \rightarrow \mathrm{CH}_{4}+\mathrm{CO}_{2}
\end{aligned}
$$




\subsubsection{Air Bleeding}

Air bleeding is a technique consisting of injecting a small amount of air or $\mathrm{O}_{2}$ into the anode supply gas and has been studied as a $\mathrm{CO}$ poisoning mitigation technique. Air bleeding was proposed by Gottesfeld and Pafford [17] in 1988, and the amount of air bleed varies depending on the cell and stack used in the study, but in most cases, it is set at approximately $0.5 \sim 5 \%$. Lung et al. [18] conducted a long-term durability test on a single cell, bleeding the anode with air for $3000 \mathrm{~h}$, and showed that the cell output voltage was reduced to approximately $97 \%$ after $3000 \mathrm{~h}$ of the constant current operation, and no severe performance degradation due to $\mathrm{CO}$ was observed. However, because there are variations in the temperature distribution and concentration in different parts of the stack, it is necessary to evaluate the mitigation effect of $\mathrm{CO}$ poisoning on the stack.

The flow rate of the injected air was adjusted using a needle valve to maintain the air concentration in the anode gas constant. During air bleeding, the $\mathrm{CO}$ on the catalyst is oxidized by the oxygen in the air to form $\mathrm{CO}_{2}$. However, excessive air bleeding may produce hydrogen peroxide $\left(\mathrm{H}_{2} \mathrm{O}_{2}\right)$, which can cause the chemical degradation of the fuel cell and should be applied with caution. The reaction of $\mathrm{CO}_{2}$ formation by air bleeding is expressed in Equation (6).

$$
\mathrm{CO}+\frac{1}{2} \mathrm{O}_{2} \rightarrow \mathrm{CO}_{2}
$$

\section{Simulation and Its Conditions}

In this study, a circulation system using biogas-derived crude hydrogen as the feed gas was developed using DWSIM [19], and the changes in the $\mathrm{CO}$ and $\mathrm{CH}_{4}$ concentrations of the methanation reaction's products with the gas reuse rate in the recirculation system were simulated. From the calculation results, the possibility of using biogas-derived hydrogen in a recirculation system for fuel cells was investigated. A process simulator is a useful tool for developing a hydrogen recirculation system for continuous hydrogen reactors. The simulator can be used to construct a hydrogen recirculation system and evaluate parameters such as the composition and concentration changes of gas components.

The process flow diagram (PFD) of the biogas fuel cell system is shown in Figure 4. In this study, the gas consumption and composition change in the hydrogen recirculation system, assuming the use of a PEMFC, were calculated. Equations (4) and (5), shown in the previous section, are incorporated into the conversion reactor as the methane production reaction. The gas flow in each part of the system is represented by "M2" to "M7" and the heat flow by "E1" to "E5." The gas components to be studied were one type of biogasderived crude hydrogen $\left(\mathrm{H}_{2}, 60 \% ; \mathrm{CO}_{2}, 30 \% ; \mathrm{CO}, 10 \mathrm{ppm} ; \mathrm{CH}_{4}, 3 \% ; \mathrm{N}_{2}, 6 \%\right)$ and $\mathrm{H}_{2} \mathrm{O}$ produced by the methanation reaction. The other operating conditions are listed in Table 1.

The reuse rate of the supplied gas was set at $90 \%, 75 \%$, and $50 \%$, and the net amount of supplied gas corresponding to the gas not reused and disposed of was supplied from the simulated gas, mixed with the circulating gas in MIX-1, and supplied to the hydrogen recirculation system.

Table 1. Operating conditions.

\begin{tabular}{|c|c|}
\hline Function & Value \\
\hline Gas mole fraction & $\mathrm{H}_{2}: 60 \%, \mathrm{CO}_{2}: 30 \%, \mathrm{CO}: 10 \mathrm{ppm}, \mathrm{CH}_{4}: 3 \%, \mathrm{~N}_{2}: 6 \%$ \\
\hline Flow rate $\left(\mathrm{m}^{3} / \mathrm{h}\right)$ & 5 \\
\hline Pressure $(\mathrm{kPa})$ & 10.0 \\
\hline Gas reuse rate $(\%)$ & $90,75,50$ \\
\hline
\end{tabular}




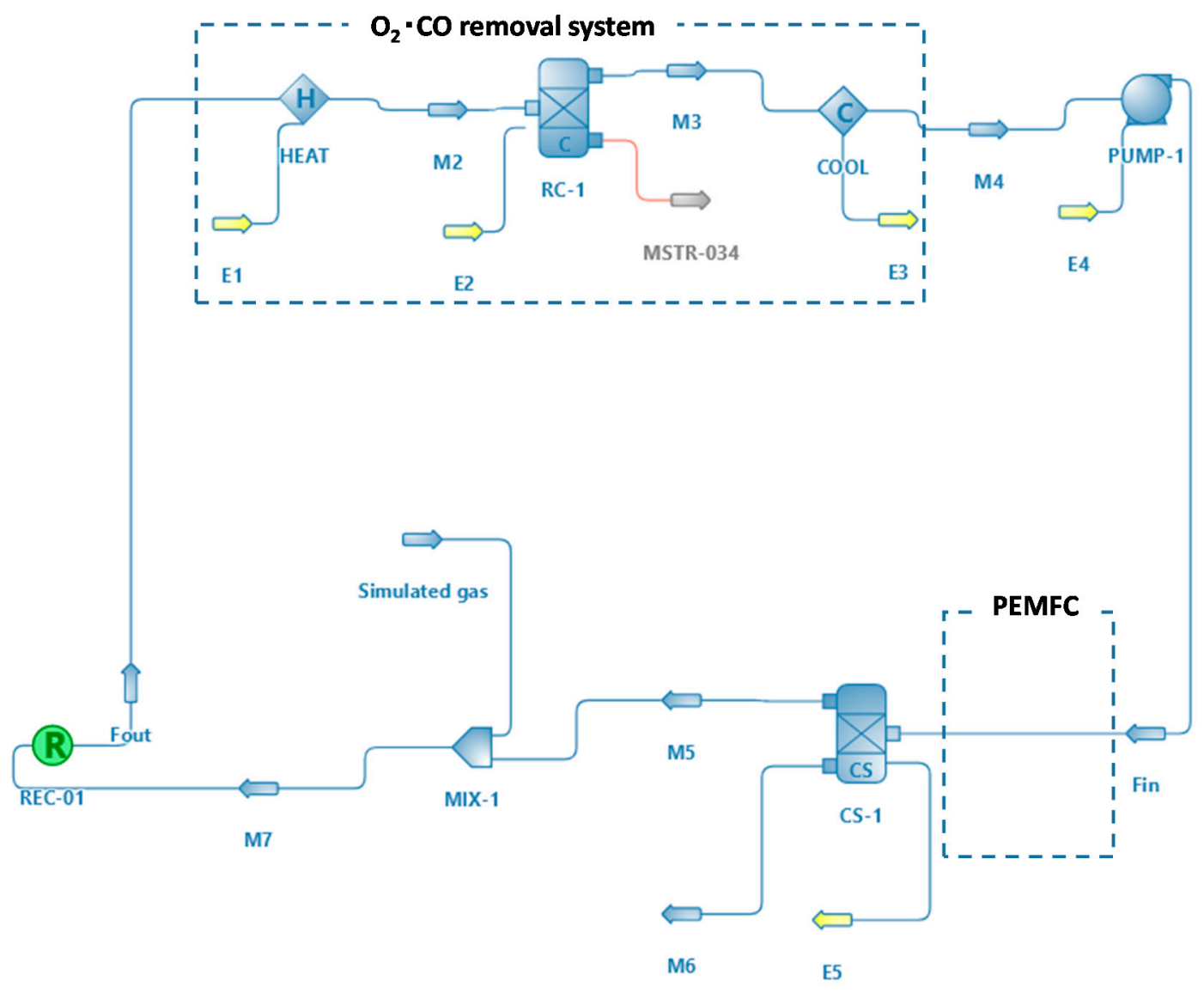

Figure 4. PFD of the biogas fuel cell system.

\section{Results of Impurity Concentration Using Process Simulation}

\subsection{Gas Reuse Rate and $\mathrm{CO}$ and $\mathrm{CH}_{4}$ Concentrations}

Simulations were performed by varying the conversion ratio of the conversion reactor, where methanation is used as a parameter. The $\mathrm{CH}_{4}$ and $\mathrm{CO}$ concentrations at "Fin" for each gas utilization ratio are shown in Figures 5 and 6, respectively. From the calculation results, the high gas reuse ratio in the process and the high conversion ratio of the methanation reactor cause a higher $\mathrm{CH}_{4}$ concentration at "Fin." On the other hand, the maximum $\mathrm{CO}$ concentration was $6.0 \times 10^{-22}$, which was so small that it could not be measured and was considered zero. This suggests that $\mathrm{CO}$ was removed by the methanation reaction to produce $\mathrm{CH}_{4}$ and that the higher the reuse rate, the higher the concentration of $\mathrm{CH}_{4}$ produced in the system. However, even when the reuse rate of the gas in the system was $90 \%$, the concentration of $\mathrm{CH}_{4}$ in the system was only approximately $3 \%$, indicating that the effect of the converted $\mathrm{CH}_{4}$ on the utilization of the fuel cell was low. 


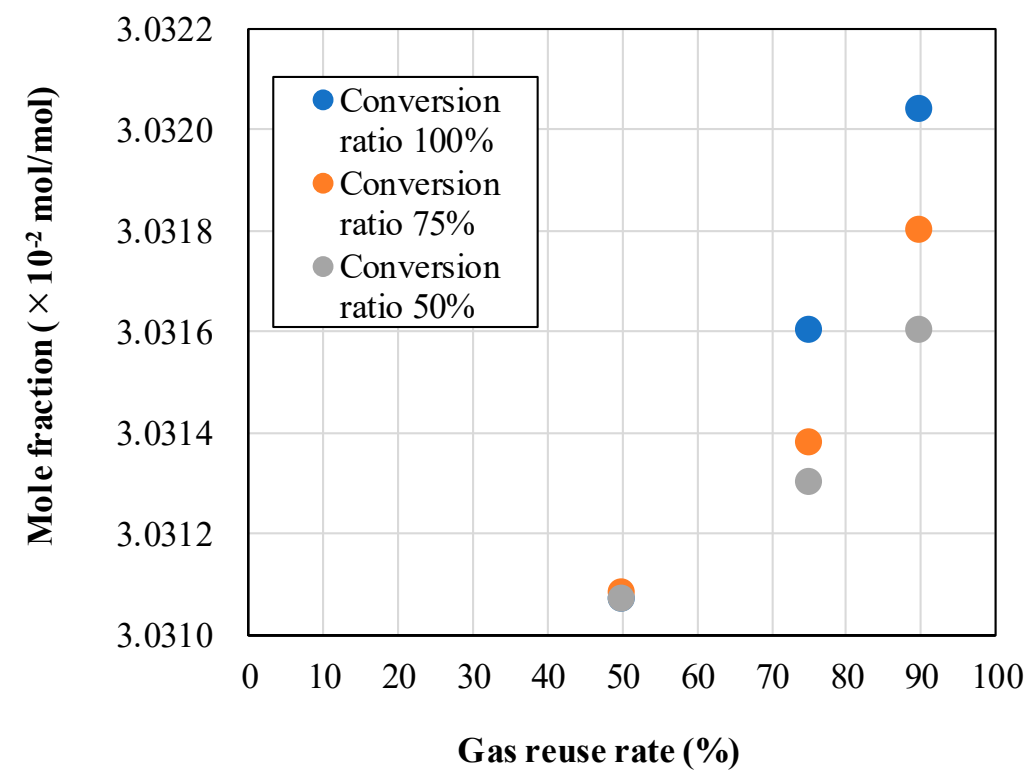

Figure 5. Simulation results of $\mathrm{CH}_{4}$ concentration for each conversion ratio at "Fin".

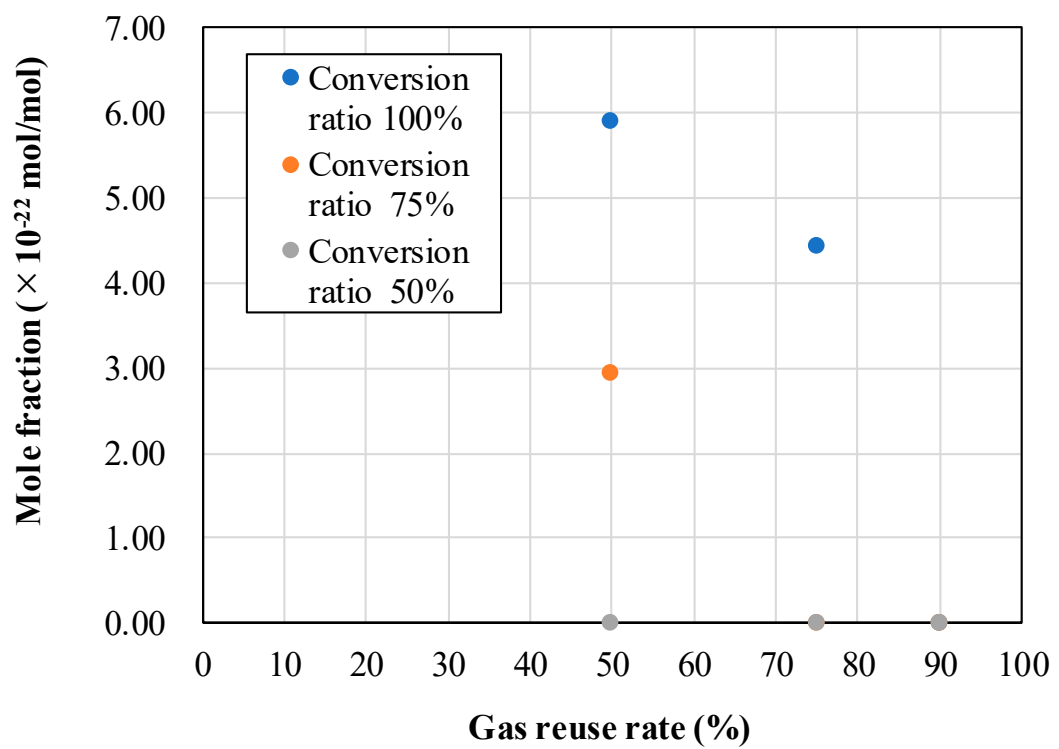

Figure 6. Simulation results of CO concentration for each conversion ratio at "Fin".

\subsection{Impurity Concentration at Each Point of the System}

The composition and flow rate in the system when the conversion rate of the methanation reactor was fixed at $100 \%$ are shown. Differences were shown for "M7", which corresponds to the gas mixed with the supplementary pure gas and supplied to the system; "M3", which corresponds to the outlet of the methanation reactor; "Fin", which corresponds to the recirculation gas supplied to the fuel cell; and "M5", which corresponds to the recirculation side after passing through the fuel cell. The simulation results of $\mathrm{CH}_{4}$ concentration, $\mathrm{CO}$ concentration, $\mathrm{N}_{2}$ concentration, $\mathrm{H}_{2} \mathrm{O}$ concentration, $\mathrm{CO}_{2}$ concentration, and flow rate at each point in the system are shown in Figure 7a-f, respectively. In terms of the $\mathrm{CH}_{4}$ concentration at each point (Figure 7a), the higher the gas reuse rate, the higher the $\mathrm{CH}_{4}$ concentration in the system, and it exceeded $3.031 \%$ at each point for a $90 \%$ reuse rate. However, when the reuse rate was maintained at 50\%, the maximum concentration was $3.031 \%$. In both cases, the increase in $\mathrm{CH}_{4}$ concentration was too small to affect fuel cell utilization. The $\mathrm{CO}$ concentration shown in Figure $7 \mathrm{~b}$ was almost zero after the addition of the methanation reactor, and it is almost zero regardless of the gas reuse rate, even 
for "Fin", where fuel cells are considered to be installed in the system. In "M7", the CO concentration was lower with a higher gas reuse rate because the gas from the methanation reaction is circulated in the system, and the $\mathrm{CO}$ fraction in the circulating gas is lower because less pure gas is supplemented. For the $\mathrm{N}_{2}$ concentration shown in Figure $7 \mathrm{c}$, the higher the gas reuse rate, the more $\mathrm{N}_{2}$ was retained in the system, and the simulation results show a difference in the mole fraction depending on the reuse rate. In particular, the $\mathrm{N}_{2}$ concentration was high when the reuse rate was $90 \%$ and $6.062 \%$. The mole fraction of $\mathrm{H}_{2} \mathrm{O}$ in the system was higher when the gas reuse rate was higher, as shown in Figure $7 \mathrm{~d} . \mathrm{H}_{2} \mathrm{O}$ is favorable for maintaining the performance of the electrolyte membrane in PEMFCs, and the concentration of $\mathrm{H}_{2} \mathrm{O}$ in the system is low enough to be used in the fuel cell. For the $\mathrm{CO}_{2}$ concentration shown in Figure 7e, the concentration in the system was $30.304 \%$ at all gas utilization rates, $\mathrm{CO}_{2}$ did not have the same impact as $\mathrm{CO}$ in ppm, and the performance degradation was similar to the dilution effect. The flow rate evaluation results (Figure 7f) showed a significant difference in the flow rates of ("M7" and "M3") before and after the methanation reactor. This is thought to be because the amount of $\mathrm{CH}_{4}$ and water produced after passing through the methanation reactor increases, and the overall flow rate also increases.

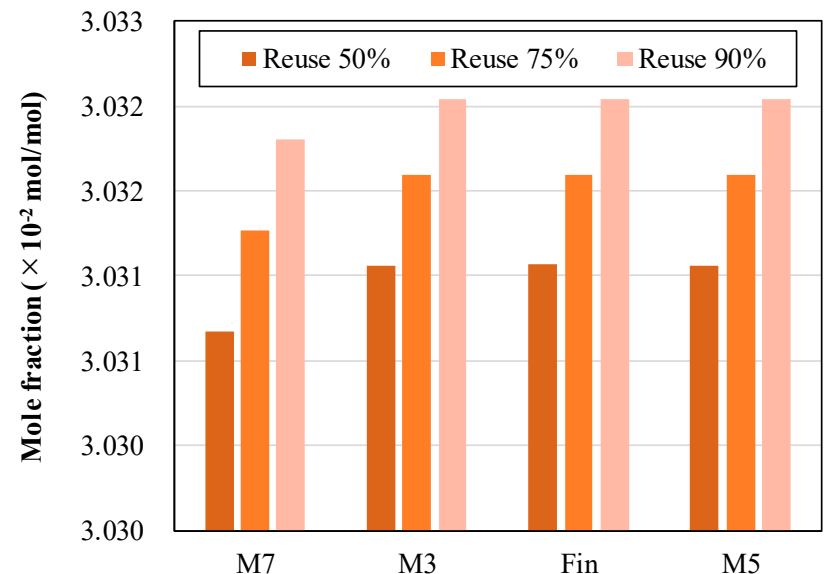

(a)

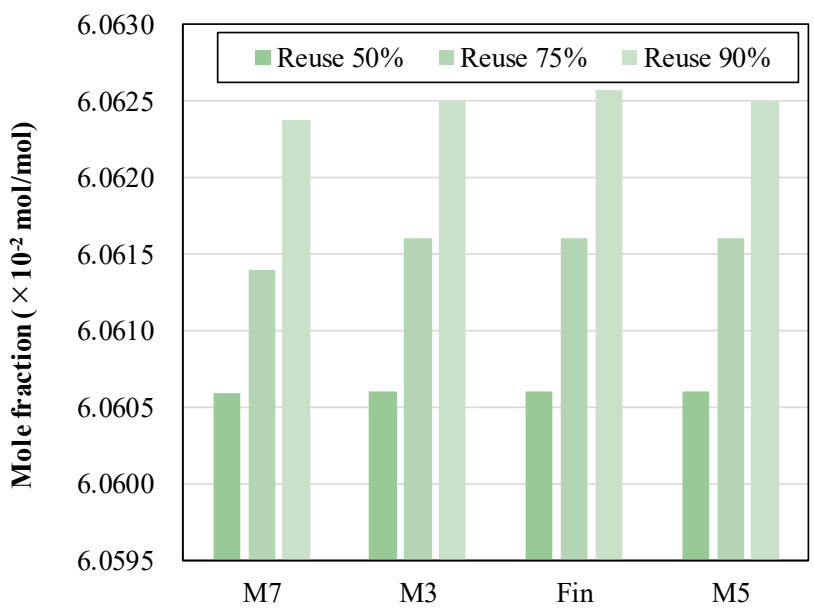

(c)

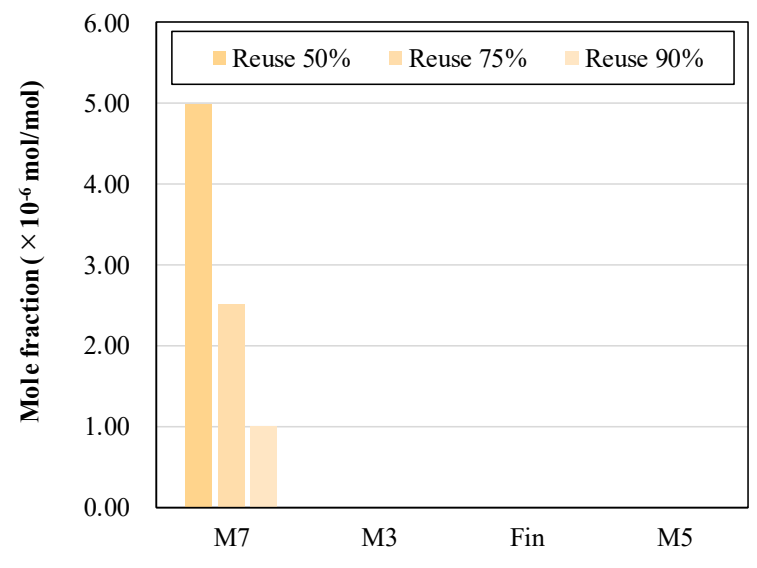

(b)

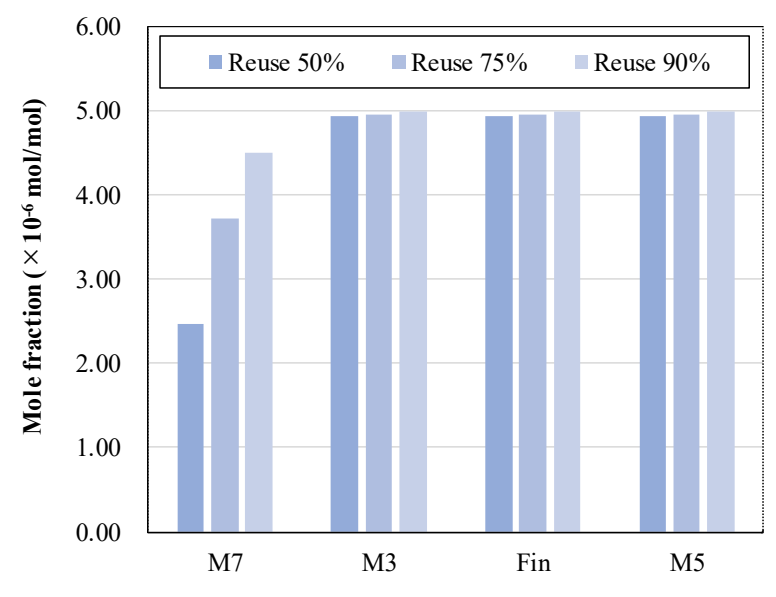

(d)

Figure 7. Cont. 


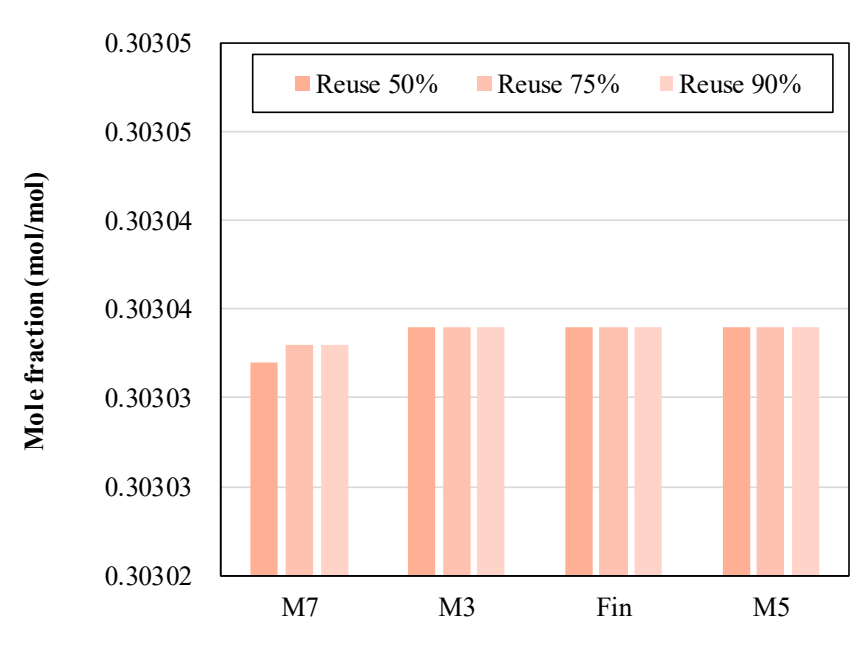

(e)

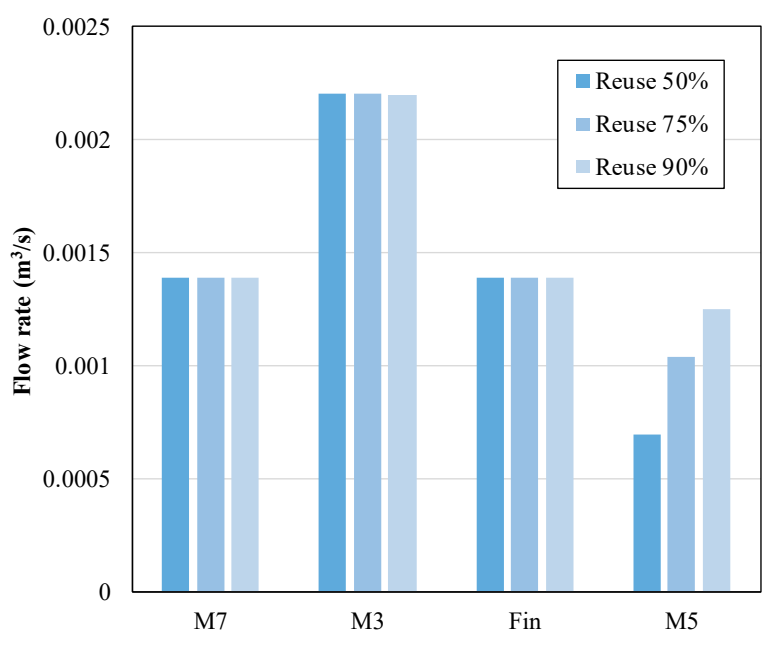

(f)

Figure 7. Simulation results of concentration and flow rate at each point; (a) $\mathrm{CH}_{4}$, (b) $\mathrm{CO}$, (c) $\mathrm{N}_{2}$, (d) $\mathrm{H}_{2} \mathrm{O}$, (e) $\mathrm{CO}_{2}$, (f) Flow rate.

Under all conditions, the impurity concentration remained at a level that did not pose a problem to the PEMFC performance, indicating that the use of biogas-derived hydrogen in the hydrogen recirculation system for fuel cells can be expected.

\section{Performance of the Fuel Cell System Using the Mitigation Operation}

\subsection{Effects of the Mitigation Operation by Methanation}

A constant voltage test of the PEMFC stack was conducted in the methanation reactor to evaluate the change in the PEMFC performance when the simulated gas was supplied. These experiments were used in flow mode, in which the control valve at the anode gas outlet is removed. The composition of the supplied gas was the same as in the simulation in the previous section: $\mathrm{H}_{2}: 60 \%, \mathrm{~N}_{2}: 36 \%, \mathrm{CH}_{4}: 3 \%$, and $\mathrm{CO}: 10 \mathrm{ppm}$. To evaluate the influence of $\mathrm{CO}$ poisoning and inert gas dilution, the $\mathrm{CO}_{2}$ contained in the biogas-derived crude refinery gas, which can produce radicals as well as $\mathrm{CO}$ [6], was replaced by $\mathrm{N}_{2}$. For a restored performance after the experiment with biogas, the stack was operated by supplying pure hydrogen until the current returned to the initial value. Moreover, the stack operated for $30 \mathrm{~min}$ by supplying pure hydrogen before supplying biogas.

Figure 8 shows the variation in the output current when the methanation reforming method was applied to the PEMFC stack. The results show that the output current of the PEMFC stack when the methanation reactor was used showed performance degradation and then reached a steady-state value by the end of the test. In the case of hydrogen stoichiometry ratio 1.1, at the same flow rate as when the simulated gas was directly supplied, a current drop of about 5 A was observed immediately after the start of the supply, followed by a gradual decrease with a constant gradient. Five hours after the start of the test, the current value reached and maintained a steady value of approximately $9 \mathrm{~A}$. The final PEMFC power generation performance after $6 \mathrm{~h}$ of simulated gas supply was approximately $50 \%$ lower than that before the simulated gas supply. Under these operating conditions, Equations (4) and (5), in which $\mathrm{CO}$ was converted to $\mathrm{CH}_{4}$ on the catalyst in the reactor, reduced the performance degradation. In contrast, when the flow rate of the entire simulated gas was increased and the hydrogen stoichiometry ratio was increased to 1.7, the current value decreased by approximately $4 \mathrm{~A}$ in the first hour after the start of the supply; however, it maintained a steady value of approximately 14 A. The final PEMFC performance at the end of the test was reduced by approximately $21 \%$ compared with the supply of the simulated gas. 


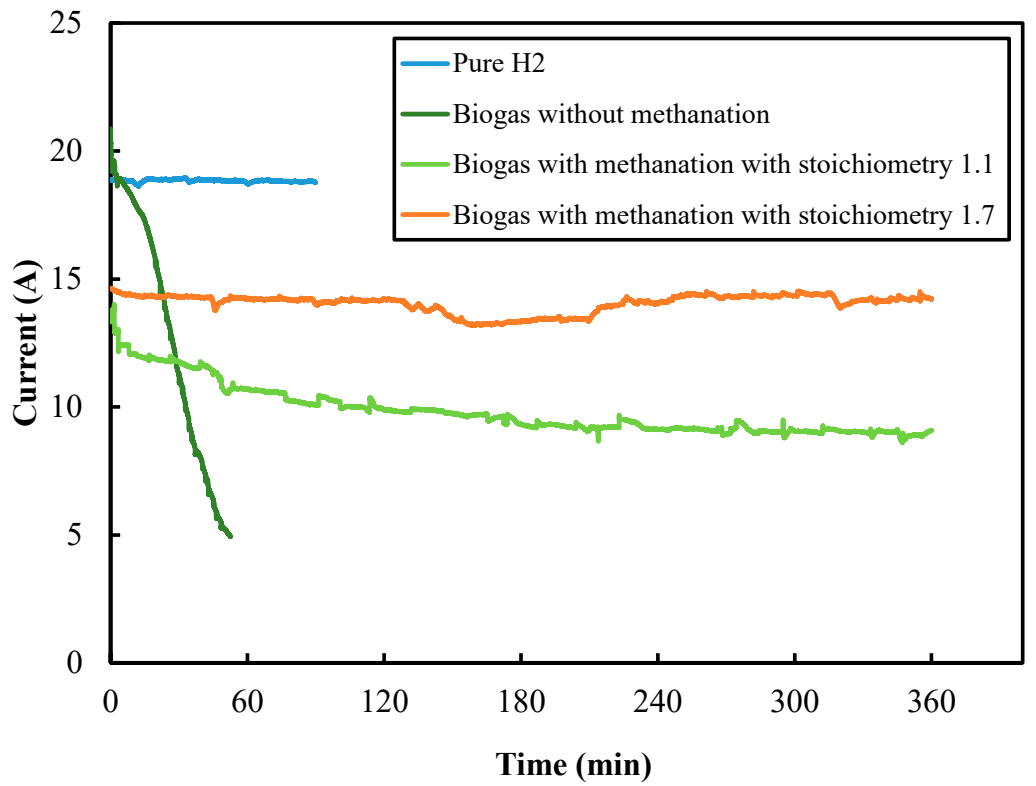

Figure 8. Comparison of the variation of the output current using pure $\mathrm{H}_{2}$, with and without the methanation reforming method.

To identify and quantify the causes of the different voltage drops due to the different hydrogen stokes and the change in performance when the methanation reforming method was applied to the simulated gas supply, we tried to evaluate each overpotential using the method used in a previous study [20]. This method is needed to calculate the IR-free voltage using the average cell resistance $R$. In this study, $R$ was $0.120 \Omega \mathrm{cm}^{2}$, as measured by current interrupt testing [15]. Then, the overpotentials calculated under all of the cell resistance were constant in the I-V curve. This method is useful for separating the activation, ohmic, and concentration overpotentials from the I-V curve data [20].

Figure 9 shows comparisons of the overpotentials with currents of 0.6 and $10 \mathrm{~A}$ for each stoichiometry ratio. In the low current range of $0.6 \mathrm{~A}$, the activation overpotential was similar for each stoichiometry ratio, but the concentration overpotential increased by a factor of 2.5 for stoichiometry ratio 1.1 compared to 1.7. This trend was also observed in the 10 A current range, with the concentration overpotential in stoichiometric ratio 1.1 being twice that of 1.7. In the activation overpotential, the difference in overpotential was small because the composition of the supplied gas did not change, even though the amount of fuel supplied changed by increasing the hydrogen stoichiometry ratio. In contrast, the difference in concentration overpotential due to the decrease in the concentration of reactants related to the hydrogen flow rate on the electrode surface was large. In the case of stoichiometric ratio 1.1, the fuel supply was only the minimum amount of hydrogen used for the electrochemical reaction, and nitrogen and methane were also present, so the diffusion law was locally impaired on the electrode surface in the stack, resulting in an increase in the hydrogen concentration gradient and the concentration overpotential. The overpotential increased at higher currents, which are expected in actual fuel cell system operation, and the difference in the magnitude of the concentration overpotential due to the difference in the hydrogen stoichiometry ratio was shown. 


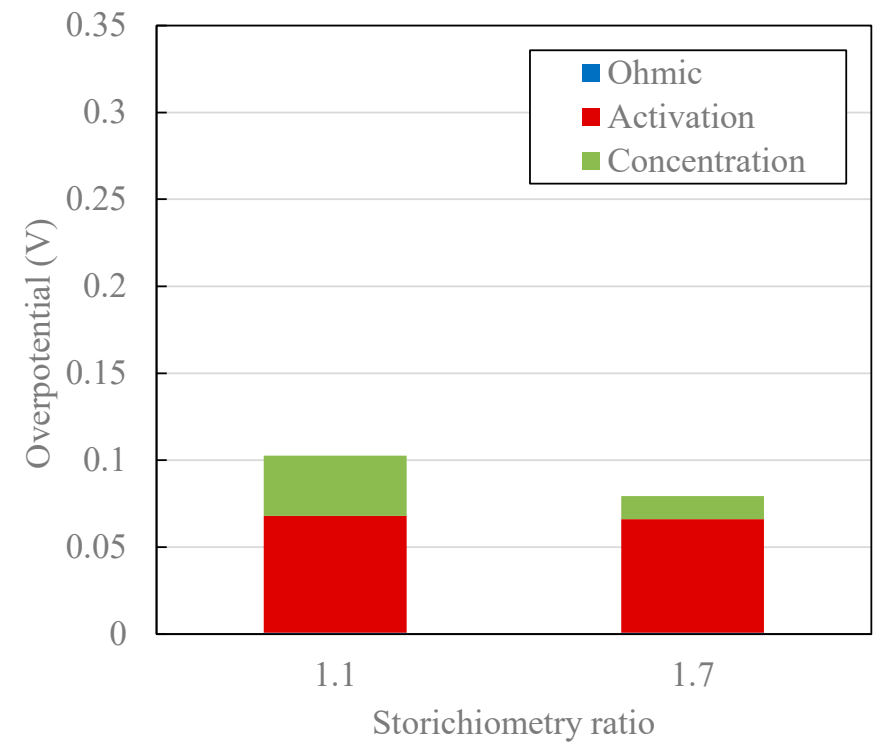

(a)

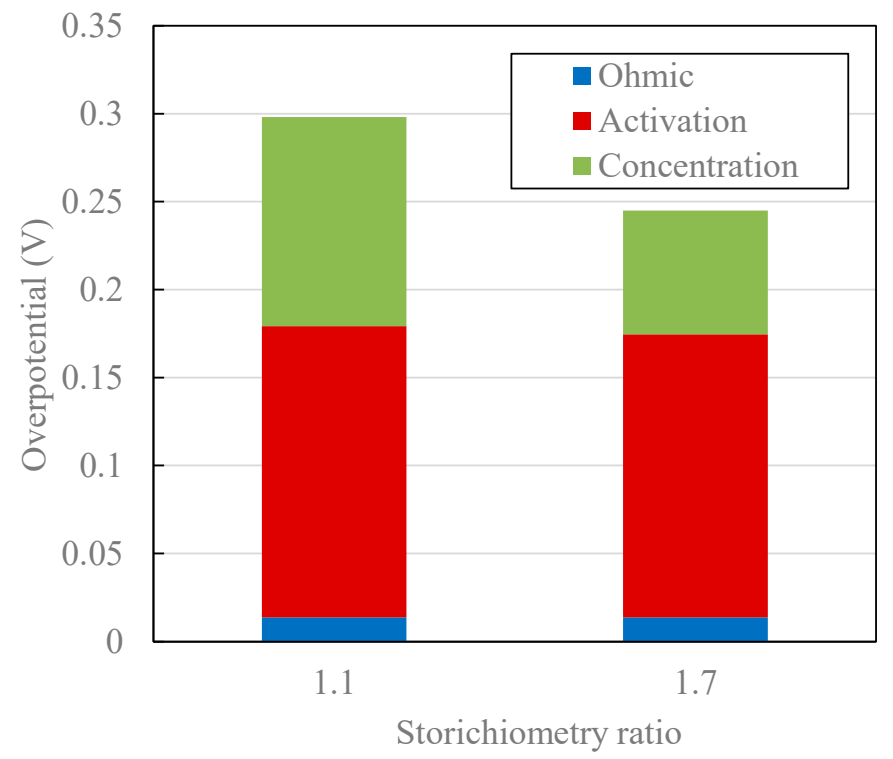

(b)

Figure 9. Comparison of the overpotentials for each stoichiometry ratio; (a) $0.6 \mathrm{~A}$, (b) $10.0 \mathrm{~A}$.

\subsection{Comparison of Mitigation Effect by Methanation and Air Bleeding}

The air bleeding method was used to evaluate the change in PEMFC performance during a constant voltage operation when the simulated gas was supplied to evaluate the mitigation effect of methanation. The composition of the simulated gas supplied was $\mathrm{H}_{2}$ : $60 \%, \mathrm{~N}_{2}: 36 \%, \mathrm{CH}_{4}: 3 \%, \mathrm{CO}: 10 \mathrm{ppm}$, and $1 \%$ air was injected at the time of gas supply to reduce the performance degradation caused by impurities.

Figure 10 shows the variation in the output current with $1 \%$ air bleed compared to methanation. As a result of the constant voltage test with $1 \%$ air added to the simulated gas, a current drop of approximately 6 A was observed immediately after the start of the supply, and the current decreased with a constant gradient. The current decreased at a constant gradient and further decreased at a slower rate after approximately $180 \mathrm{~min}$ from the start of the test. Finally, after $6 \mathrm{~h}$ of operation, the current was $6.60 \mathrm{~A}$, which is approximately $63 \%$ lower than that before the supply of simulated gas. The current was 2 A lower than that of methanation reforming with the stoichiometric ratio 1.1, where the fuel supply was the same. The partial pressure of hydrogen in the methanation reforming was only $1 \%$ different, suggesting that factors other than the difference in partial pressure are responsible for this performance difference.

The overpotentials at $0.6 \mathrm{~A}$ and $8 \mathrm{~A}$ are shown in Figure 11a,b. In the low current range $(0.6 \mathrm{~A})$, the activated overpotential was larger in the air bleeding method. For the low current range of $0.6 \mathrm{~A}$, the activation overpotential was larger in the air bleed method, and the activation overpotential accounts for $88 \%$ of the overvoltage in the air bleed method. In the current range of $8 \mathrm{~A}$, the activation overpotential of the air bleed method was large, 1.5 times larger than that of methanation. The overvoltage in the current range of $8 \mathrm{~A}$ is 1.2 times larger in the air bleeding method than in the methanation modification. Because the difference in concentration and ohmic overpotential is small for both methods, the difference in PEMFC performance between the air bleeding and methanation methods can be attributed to the magnitude of the activation overpotential. In the case of air bleeding, CO was adsorbed on the catalyst on the PEMFC electrode surface, and more activation energy may be consumed during $\mathrm{CO}$ oxidation. The loss of activation energy may have affected the performance of the PEMFC as the activation overpotential, which was expressed as a decrease in the current. Therefore, in addition to the difference in hydrogen partial pressure due to the addition of $1 \%$ air, the increase in overvoltage during 
$\mathrm{CO}$ oxidation is thought to be a factor in the lower power generation performance of the air bleed method, despite the similar hydrogen stoichiometry ratio.

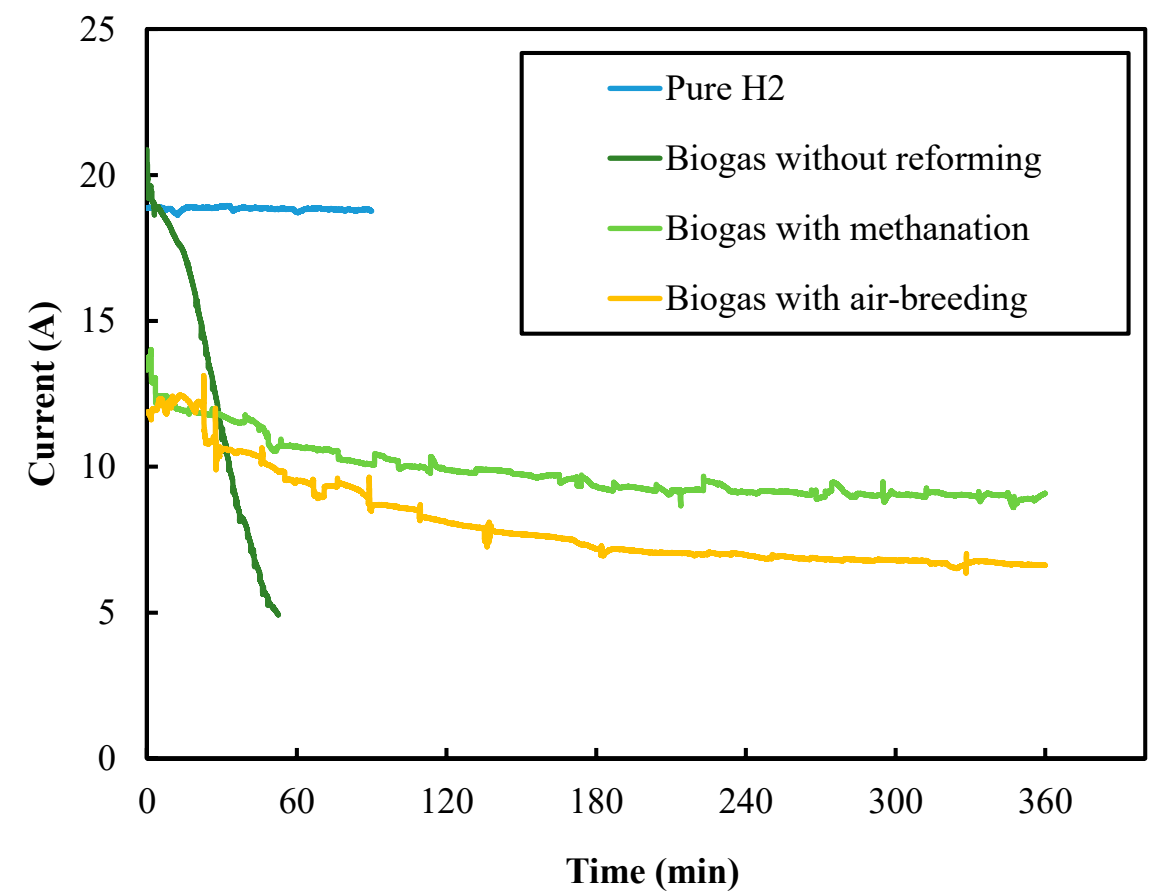

Figure 10. Comparison of the variation of the output current using pure $\mathrm{H}_{2}$, with and without the methanation reforming method.

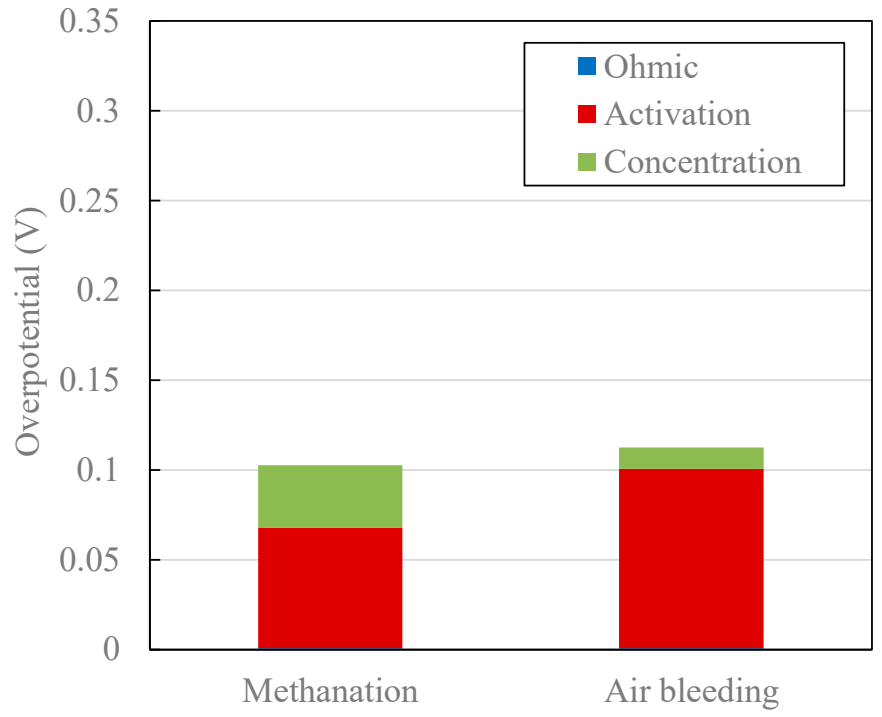

(a)

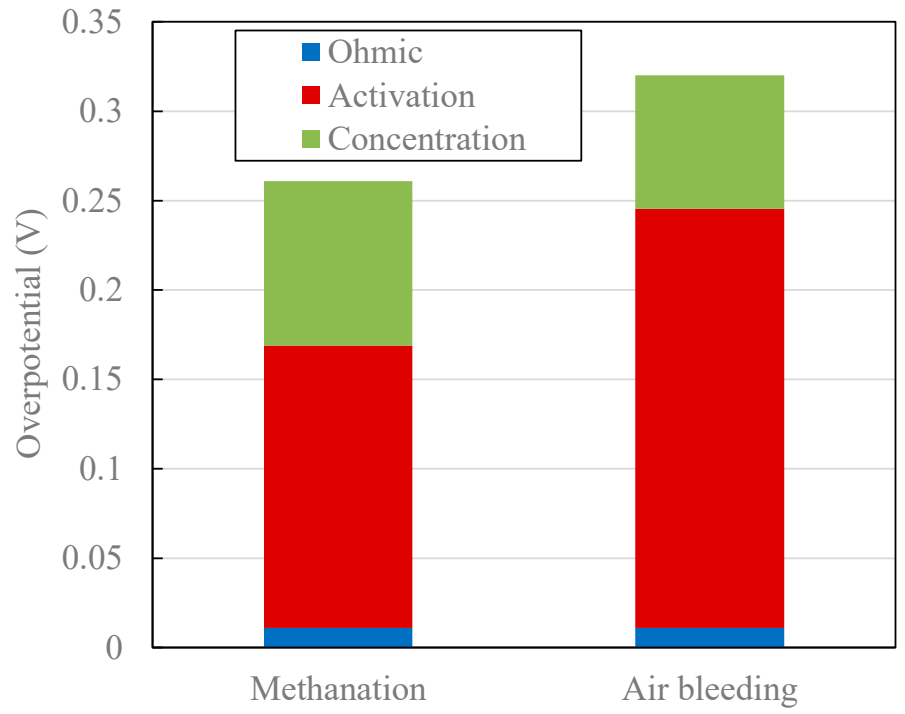

(b)

Figure 11. Comparison of the overpotentials at stoichiometry ratio 1.1 for each mitigation operation; (a) $0.6 \mathrm{~A},(\mathbf{b}) 8.0 \mathrm{~A}$.

\section{Conclusions}

The simulation of impurities in the hydrogen recirculation system and the mitigation operation using simple purification methods were evaluated to develop a fuel cell system for the effective utilization of biogas-derived hydrogen.

The $\mathrm{CH}_{4}$ concentration in the fuel cell was higher when the gas utilization rate was higher because of the higher conversion rate of the methanation reaction. $\mathrm{N}_{2}$ and $\mathrm{CO}_{2}$ 
remain in the system at the same concentration as that of the supplied gas, and the dilution effect may affect the performance of the fuel cell system. The concentration of $\mathrm{H}_{2} \mathrm{O}$ produced during the methanation reaction was only ppm level under all the conditions evaluated, which is favorable for maintaining the performance of the PEMFC electrolyte membrane. The concentration of impurities in the PEMFCs under all the conditions remained at a level that did not pose a problem to the PEMFC performance, indicating that the use of biogas-derived hydrogen in the hydrogen recirculation system for fuel cells was promising.

The conditions for applying the methanation reforming and air bleeding methods were clarified in the constant voltage test for a simulated gas supply of biogas-derived hydrogen. The methanation reforming method was applied to reduce the performance degradation caused by impurities, and it was shown that a continuous operation with constant performance was possible. In the case of a hydrogen stoichiometry ratio of 1.7, a current drop of approximately $4 \mathrm{~A}$ was observed in the first hour after the start of supply, but the performance drop was suppressed to approximately $21 \%$ in $6 \mathrm{~h}$. By increasing the fuel flow rate, the hydrogen stoichiometry ratio supplied to the fuel cell can be increased, effectively maintaining the performance. When the air bleed method was applied, the current value gradually decreased after the start of the supply, and, finally, the performance decreased by approximately $63 \%$ in $6 \mathrm{~h}$. During the air bleeding method, the performance was lower than that during methanation reforming, and the polarization evaluation revealed that the performance was significantly reduced by two effects: the decrease in hydrogen's partial pressure and the overvoltage during CO oxidation. Therefore, a continuous operation by methanation reforming is more suitable for supplying biogas containing $\mathrm{CO}$.

In this study, the composition of biogas from the previous study was used, but depending on the composition of other gases, the amount of hydrogen may not be sufficient, and the performance may be degraded owing to mass transport loss. Therefore, it is necessary to consider the hydrogen stoichiometry ratio in the fuel supply. In particular, because biogas has low hydrogen purity and low partial pressure, it is desirable to produce gas with a high hydrogen fraction, as much as possible, and supply it to the system.

Author Contributions: Data curation, Y.M.; Formal analysis, Y.A.; Investigation, Y.A. and Y.M.; Methodology, Y.M.; Supervision, K.O.; Visualization, Y.A. and Y.M.; Writing-original draft, Y.A. and Y.M.; Writing-review \& editing, Y.M. and K.O. All authors have read and agreed to the published version of the manuscript.

Funding: This research received no external funding.

Conflicts of Interest: The authors declare no conflict of interest.

\section{References}

1. Nishizaki, K.; Umetsu, K.; Takahashi, J.; Adachi, J.; Kobayashi, S. A study on the PEMFC generator fueled by biogas from livestock manure. J. Jpn. Soc. Agric. Mach. 2002, 64, 154-156.

2. Papadias, D.D.; Ahmed, S.; Kumar, R. Fuel quality issues with biogas energy-An economic analysis for a stationary fuel cell system. Energy 2012, 44, 257-277. [CrossRef]

3. Alves, H.J.; Junior, C.B.; Niklevicz, R.R.; Frigo, E.P.; Frigo, M.S.; Coimbra-Araújo, C.H. Overview of hydrogen production technologies from biogas and the applications in fuel cells. Int. J. Hydrog. Energy 2013, 38, 5215-5225. [CrossRef]

4. Klages, M.; Tjønnås, J.; Zenith, F.; Halvorsen, I.J.; Scholta, J. Dual control of low concentration CO poisoning by anode air bleeding of low temperature polymer electrolyte membrane fuel cells. J. Power Sources 2016, 336, 212-223. [CrossRef]

5. Xuan, J.; Leung, M.K.H.; Leung, D.Y.C.; Ni, M. A review of biomass-derived fuel processors for fuel cell systems. Renew. Sustain. Energy Rev. 2009, 13, 1301-1313. [CrossRef]

6. Sung, L.-Y.; Hwang, B.-J.; Hsueh, K.-L.; Su, W.-N.; Yang, C.-C. Comprehensive study of an air bleeding technique on the performance of a proton-exchange membrane fuel cell subjected to CO poisoning. J. Power Sources 2013, 242, 264-272. [CrossRef]

7. Besancon, B.M.; Hasanov, V.; Imbault-Lastapis, R.; Benesch, R.; Barrio, M.; Mølnvik, M.J. Hydrogen quality from decarbonized fossil fuels to fuel cells. Int. J. Hydrogen Energy 2009, 34, 2350-2360. [CrossRef]

8. Chen, C.Y.; Huang, K.P. Performance and transient behavior of the kW-grade PEMFC stack with the Pt-Ru catalyst under CO-contained diluted hydrogen. Int. J. Hydrogen Energy 2017, 42, 22250-22258. [CrossRef] 
9. Tingelöf, T.; Hedström, L.; Holmström, N.; Alvfors, P.; Lindbergh, G. The influence of $\mathrm{CO}_{2}, \mathrm{CO}$ and air bleed on the current distribution of a polymer electrolyte fuel cell. Int. J. Hydrog. Energy 2008, 33, 2064-2072. [CrossRef]

10. Smolinka, T.; Heinen, M.; Chen, Y.X.; Jusys, Z.; Lehnert, W.; Behm, R.J. $\mathrm{CO}_{2}$ reduction on Pt electrocatalysts and its impact on $\mathrm{H}_{2}$ oxidation in $\mathrm{CO}_{2}$ containing fuel cell feed gas-A combined in situ infrared spectroscopy, mass spectrometry and fuel cell performance study. Electrochim. Acta 2005, 50, 5189-5199. [CrossRef]

11. Xu, G.; Chen, X.; Honda, K.; Zhang, Z.-G. Producing $\mathrm{H}_{2}$-rich gas from simulated biogas and applying the gas to a $50 \mathrm{~W}$ PEFC stack. AIChE J. 2004, 50, 2467-2480. [CrossRef]

12. Matsuda, Y.; Shimizu, T.; Mitsushima, S. Adsorption behavior of low concentration carbon monoxide on polymer electrolyte fuel cell anodes for automotive applications. J. Power Sources 2016, 318, 1-8. [CrossRef]

13. Minei, Y.; Okajima, K.; Yasuda, M.; Ube, R. PEMFC System for Utilization of Exhaust Gas from Bright Heat Treatment furnace. In Proceedings of the 12th International Conference on Applied Energy, Virtual Conference, 1-10 December 2020.

14. Horizon Fuel Cell Technologies. H-1000 Fuel Cell Stack User Manual; Horizon Fuel Cell Technologies: Singapore, 2016.

15. Mennola, T.; Mikkola, M.; Noponen, M.; Hottinen, T.; Lund, P. Measurement of ohmic voltage losses in individual cells of a PEMFC stack. J. Power Sources 2002, 112, 261-272. [CrossRef]

16. Cooper, K.R.; Smith, M. Electrical test methods for on-line fuel cell ohmic resistance measurement. J. Power Sources 2006, 160, 1088-1095. [CrossRef]

17. Gottesfeld, S.; Pafford, J. A New Approach to the Problem of Carbon Monoxide Poisoning in Fuel Cells Operating at Low Temperatures. J. Electrochem. Soc. 1988, 135, 2651-2652. [CrossRef]

18. Sung, L.-Y.; Hwang, B.-J.; Hsueh, K.-L.; Tsau, F.-H. Effects of anode air bleeding on the performance of CO-poisoned protonexchange membrane fuel cells. J. Power Sources 2010, 195, 1630-1639. [CrossRef]

19. DWSIM. Available online: https://dwsim.inforside.com.br/new/ (accessed on 19 May 2021).

20. Gasteiger, H.A.; Gu, W.; Makharia, R.; Mathias, M.F.; Sompalli, B. Beginning-of-Life MEA Performance-Efficiency Loss Contributions. In Handbook of Fuel Cells_Fundamental Technology and Applications; John Wiley \& Sons: Hoboken, NJ, USA, 2003; Volume 4, pp. 593-610. [CrossRef] 